\title{
KELOMPOK USAHA IKAN ASAP DI DESA PASEBAN KECAMATAN GUMUK MAS KABUPATEN JEMBER ${ }^{1)}$
}

\author{
Rindiani'2) dan Supriyono $^{3)}$ \\ 1) Dibiayai Dikti Nomor: 090/SP2H/PPM/DIT.LITABMAS/II/2015 \\ 2) Jurusan Kesehatan, Politeknik Negeri Jember \\ 3) Jurusan Teknologi Pertanian, Politeknik Negeri Jember
}

\begin{abstract}
ABSTRAK
Pengasapan ikan dari pengrajin ikan asap sebagian besar dilakukan dengan alat sederhana, yaitu berbentuk para-para (sistem terbuka) yang merupakan alat pengasapan panas dengan bahan bakar kayu bakar. Pengasapan semacam ini kurang efektif karena panas dan asap yang dikeluarkan lebih banyak terbuang sesuai arah angin daripada yang terpusat ke ikan. Alat pengasapan dingin $\left(20-50^{\circ} \mathrm{C}\right)$ belum banyak dikembangkan, padahal dari segi ketahanan ikan, ikan yang diasapi dengan pengasapan dingin memiliki daya tahan yang lebih lama dibandingkan ikan yang diasapi dengan pengasapan panas. Melihat kondisi tersebut, diperlukan pengembangan dari alat pengasapan dingin. Hasil rancangan alat yang dibuat oleh program adalah sebagai berikut: 1) bentuk bangunan alat kompak dengan sistem tertutup dibuat dari stainless steel (ST 201); 2) kapasitas terdiri dari 3 rak; 4) bahan bakar tongkol jagung; 5) panas dan asap terpusat di produk dan tidak terbuang karena ada cerobong asap; 6) kualitas ikan asap yang dihasilkan; warna kuning keemasan, aroma, tekstur dan rasa sedang; 7) alat tidak terpengaruhi oleh kondisi angin /hujan; serta 8) pemeliharaan tidak sulit.
\end{abstract}

Kata kunci: alat pengasap, ikan, rancangan

\section{PENDAHULUAN}

\section{1 Analisis Situasi}

Potensi perikanan Indonesia sangat besar, dimana potensi lestari perikanan Indonesia diperkirakan mencapai 6,7 juta ton/tahun. Hingga saat ini potensi yang termanfaatkan baru sebesar 59 \% (Direktorat Kredit, BPR dan UMKM, 2009), sehingga pengembangan produk olahan perikanan ke arah industri masih menjanjikan.

Total pemanfaatan produk perikanan Indonesia sebagian besar dikonsumsi dalam kondisi segar $(43,1 \%)$, beku $(30,4 \%)$, pengalengan $(13,7 \%)$ dan dalam bentuk olahan lain $(12,8 \%)$ (Direktorat Kredit, BPR dan UMKM, 2009). Menurut Menurut Astawan (1997), bentuk olahan ikan berupa ikan asin, ikan asap, ikan pindang dan produk fermentasi (petis, terasi, peda). Adapun besaran produk pengolahan ikan terdiri atas olahan: penggaraman $(30,5 \%)$, pemindangan $(5,4 \%)$, fermentasi $(2,4)$, pengasapan $(1,8 \%)$, pengawetan lain (1\%), pembekuan $(6,2 \%)$, pengalengan $(1,2 \%)$, dan pembuatan tepung ikan (0,5\%)(Astawan, 1997).

Produk pengasapan ikan di Indonesia mulai berkembang dengan tingkat konsumsi dari tahun ke tahun cenderung meningkat, meskipun masih di bawah dari beberapa negara maju yang tingkat konsumsi produk ikan asap sangat tinggi (Hukmi, 2010). Oleh karenanya dibutuhkan peningkatan produksi dan kualitas produk ikan asap dari produsen ikan asap.

Pengasapan ikan dari pengrajin ikan asap sebagian besar dilakukan dengan alat sederhana, yaitu berupa rumah berbentuk para-para (sistem terbuka) merupakan alat pengasapan 
panas (suhu $60-120^{\circ} \mathrm{C}$ ) dengan bahan bakar kayu bakar. Pengasapan semacam ini kurang efektif karena panas dan asap yang dikeluarkan lebih banyak terbuang sesuai arah angin daripada yang terpusat ke ikan. Dengan demikian, untuk menghasilkan ikan asap diperlukan waktu yang relatif lama dan juga ikan yang dihasilkan berkualitas rendah, baik dari segi rasa, warna, tekstur dan aroma (Maripul, 2001; Adawyah, 2007).

Alat pengasapan dingin (20 $50^{\circ} \mathrm{C}$ ) belum banyak dikembangkan, padahal dari segi ketahanan ikan, ikan yang diasapi dengan pengasapan dingin memiliki daya tahan yang lebih lama dibandingkan ikan yang diasapi dengan pengasapan panas (Adawyah, 2007). Melihat kondisi tersebut, diperlukan pengembangan dari alat pengasapan dingin karena mempunyai efisiensi yang lebih baik dari segi waktu dan produk ikan asap yang dihasilkan, mempunyai mutu yang lebih baik.

\section{2 Permasalahan Mitra}

Permasalahan yang ditemui di lapangan pada proses pengasapan ikan sistem terbuka adalah:

a. Pada sistem pengasapan langsung (sistem terbuka atau panas), dibutuhkan pemakaian kayu sebagai sumber asap dalam jumlah lebih banyak.

b. Pemanfaatan asap menjadi tidak efektif (perlu waktu relatif lama) karena asap tidak langsung menuju ke pusat ikan, tetapi lebih banyak terbuang karena pengaruh arah angin.

c. Asap yang dikeluarkan menyebabkan polusi udara dan menimbulkan ketidaknyamanan bagi pekerja.

d. Tingkat higienitas pengasapan dengan sistem terbuka rendah

e. Mutu ikan asap dan daya awet rendah karena kadar air yang masih tinggi.

\subsection{Justifikasi Pengusul Bersama Mitra dalam Menentukan Persoalan Prioritas yang Disepakati untuk Diselesaikan}

Untuk menjamin keberlanjutan kemitraan terkait dengan kegiatan ini pada pengrajin ikan asap, terdapat beberapa kesepakatan kerjasama meliputi:

1. Pihak Politeknik Negeri Jember

a) Mendesain alat pengasap dingin menyangkut bahan, kapasitas dan spesifikasi sesuai dengan keperluan mitra.

b) Membuat alat pengasap dingin dengan sistem otomatisasi hasil kesepakatan bersama untuk diterapkan di kelompok pengerajin ikan asap Bapak Karlin dan Bapak Saneman.

c) Menguji kualitas ikan asap yang dihasilkan sesuai standar SNI 2725.1: 2009 meliputi: uji organoleptik, uji cemaran mikroba dan cemaran kimia.

d) Memberikan pelatihan pengoperasian alat pengasap dingin, cara merawat serta perbaikan ringan.

2. Pihak pengrajin ikan asap "Bapak Karlin" dan "Bapak Saneman".

a) Pengrajin ikan asap wajib untuk merawat dan memelihara peralatan asap metode dingin.

b) Pengrajin ikan asap wajib memproduksi ikan asap menggunakan sistem pengasapan dingin dan melaporkan kemajuan usahanya untuk keperluan pembuatan laporan akhir.

c) Bersedia menerima mahasiswa Politeknik Negeri Jember untuk kegiatan penelitian (Tugas Akhir).

\section{TARGET DAN LUARAN}

2.1 Target

Target dari kegiatan ini adalah: 
a) Meningkatkan kualitas ikan asap yang dihasilkan sesuai dengan SNI 2725.1: 2009.

b) Konsumsi bahan bakar (kayu bakar) lebih hemat, sehingga secara langsung lebih ramah lingkungan.

c) Meningkatkan target penjualan sehingga kesejahteraan pengrajin ikan asap lebih baik.

d) Produk ikan asap sesuai persyaratan SNI 2725.1: 2009 akan mendukung program One Village One Product yang dicanangkan Pemerintah Propinsi Jawa Timur di mana setiap desa mempunyai produk unggulan.

\subsection{Luaran}

Luaran dari Kegiatan ini adalah bertambahnya pengetahuan mitra tentang proses pengerjaan/pembuatan ikan asap metode dingin serta mendapatkan satu paket teknologi terintegrasi alat pengasap dingin.

\section{METODE PELAKSANAAN}

\subsection{Pembuatan Alat Pengasap Dingin}

\subsubsection{Alat dan Bahan}

Peralatan yang digunakan dalam pembuatan alat pengasap dingin adalah Tang Potong, Solder, Multimeter Digital, Klinik Robot AVR USB ISP, Microsoft Excel 2007, Gerinda Listrik, Bor listrik kecil, Eagle 5.7.0, serta Codevision AVR. Bahan yang digunakan Mikrokontroler, LCD, Sensor suhu, Sensor asap, Resistor, PCB, Batok kelapa, Arang kelapa, Ikan, Aluminium, Lembar aluminium serta plat stainless steel.

\subsubsection{Sistem Kerja Alat}

Alat pengasapan ikan metode dingin dibuat tertutup untuk mencegah udara luar masuk dan melindungi ikan faktor eksternal. Tungku pembakaran dibuat terpisah dengan ruang asap, agar suhu di ruang asap tidak melebihi $50{ }^{\circ} \mathrm{C}$ karena pada pengasapan dingin suhu yang digunakan berkisar $30-50{ }^{\circ} \mathrm{C}$.

Ruang asap memiliki satu inlet berada di rak paling bawah dan satu outlet berada pada rak yang paling atas. Terdapat lima kipas pada ruang asap, satu kipas pada rak bawah, dua kipas pada rak tengah, dan dua kipas pada rak atas. Kipas di rak bawah berfungsi menarik asap dari ruang pembakaran, sehingga asap masuk ke ruang pembakaran secara maksimal. Rak tengah terdapat kipas yang disusun secara horizontal dan vertikal. Kipas horizontal berguna mengalirkan udara di rak tengah sedangkan kipas yang menghadap secara vertikal berguna agar asap dari masukan sebagian ada yang diteruskan ke rak atas, sehingga asap tidak terlalu pekat di rak bawah dan rak tengah. Rak atas terdapat dua kipas yang tersusun horizontal, kipas pertama berfungsi mengalirkan asap dan kipas kedua mengeluarkan asap. Sirkulasi di ruang asap dibuat agar kondisi di ruang asap tidak lembab dan mempercepat proses pengasapan. Alat pengasapan ikan metode dingin mampu menampung $25 \mathrm{~kg}$ ikan.

\subsubsection{Rancangan Alat}

Rancangan dan dimensi alat dari alat pengasapan dingin dibagi menjadi dua bagian, yaitu rancangan alat dan rancangan elektronika. Rancangan alat mencakup tempat pembakaran dan ruang pengasapan. Rancangan elektronika Dimensi ruang asap berukuran 150 x 100 x $100 \mathrm{~cm}$.

\subsection{Proses Pembuatan Ikan Asap}

\subsubsection{Preparasi Ikan}

Preparasi ikan yang sempurna dapat mengurangi kerusakan pada ikan asap. Proses preparasi ikan sebagai berikut:

a. Pencucian dan penyiangan.

Ikan asap dicuci terlebih dahulu untuk menghilangkan kotoran dan lendir. Penyiangan ikan dengan cara membelah bagian perut dan membuang isi perut. Setelah itu ikan di fillet. 


\section{b. Penggaraman}

Penggaraman dilakukan dengan merendam fillet dalam larutan garam \pm 15 menit, kemudian fillet diangkat dan dikeringkan. Tujuan penggaraman adalah memudahkan pencucian dan penghilangan lendir, memberi cita rasa produk, membantu pengawetan, pengeringan menghasilkan tekstur lebih kompak (Adawyah, 2007).

\subsubsection{Proses Pengasapan}

Proses pengasapan meliputi pemilihan bahan bakar, penyusunan ikan, serta proses pengasapan. Bahan bakar yang digunakan adalah tongkol jagung kering (seperti yang dilakukan Mitra IbM). Bahan bakar ini dipilih karena tidak mengandung getah dan lebih ekonomis. Fillet disusun secara mendatar dengan jarak antar ikan $5 \mathrm{~cm}$. Agar pemanasan merata, selama proses pengasapan, ikan perlu dibalik. Pengasapan dilakukan pada suhu 30 $50{ }^{\circ} \mathrm{C}$

\section{HASIL DAN PEMBAHASAN}

\subsection{Rancang Bangun Alat Pengasap}

Alat pengasap konvensional milik mitra merupakan bangunan batu bata tanpa dikuliti dengan rak-rak terbuat dari bambu. Kondisi ini memberikan kesan yang kotor, kumuh dan tidak higienis, hal ini dikarenakan produk ikan asap mengeluarkan minyak selama proses. Minyak tersebut menempel di dinding batu bata, rak kayu dan sebagainya sehingga memberikan kesan kotor.

Berdasarkan hasil FGD (Focus
Group Discussion) diperoleh
kesepakatan untuk merancang
bangunan pengasap dengan ukuran

yang sama dengan bahan stainless steel ST 201 yang lebih bersih dan higienis. Gambaran alat pengasap mitra metode konvensional tertera pada Gambar 1, sedangkan hasil rancangan program tertera pada Gambar 2.

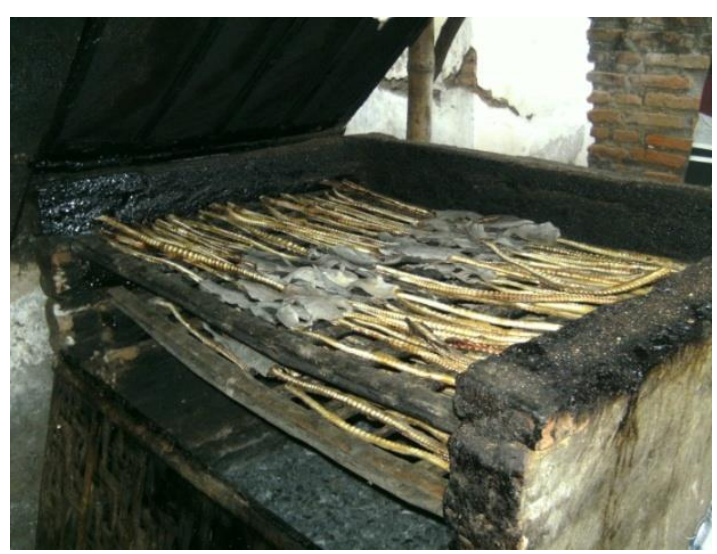

Gambar 1. Alat Pengasap Konvensional Milik Mitra

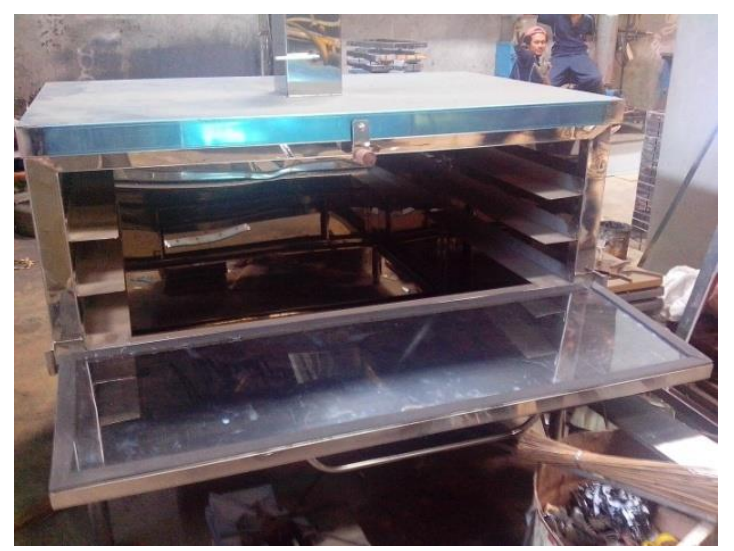

Gambar 2. Alat Pengasap Hasil Rancangan Program IbM

Rancangan desain alat pengasap hasil rancangan tertera pada Gambar 3 dan Gambar 4 yang terdiri atas: ruang pengasap, dudukan rak bambu, setelan bukaan, pintu ruang pengasapan, rak bambu, ruang pembakaran dan tutup tungku 


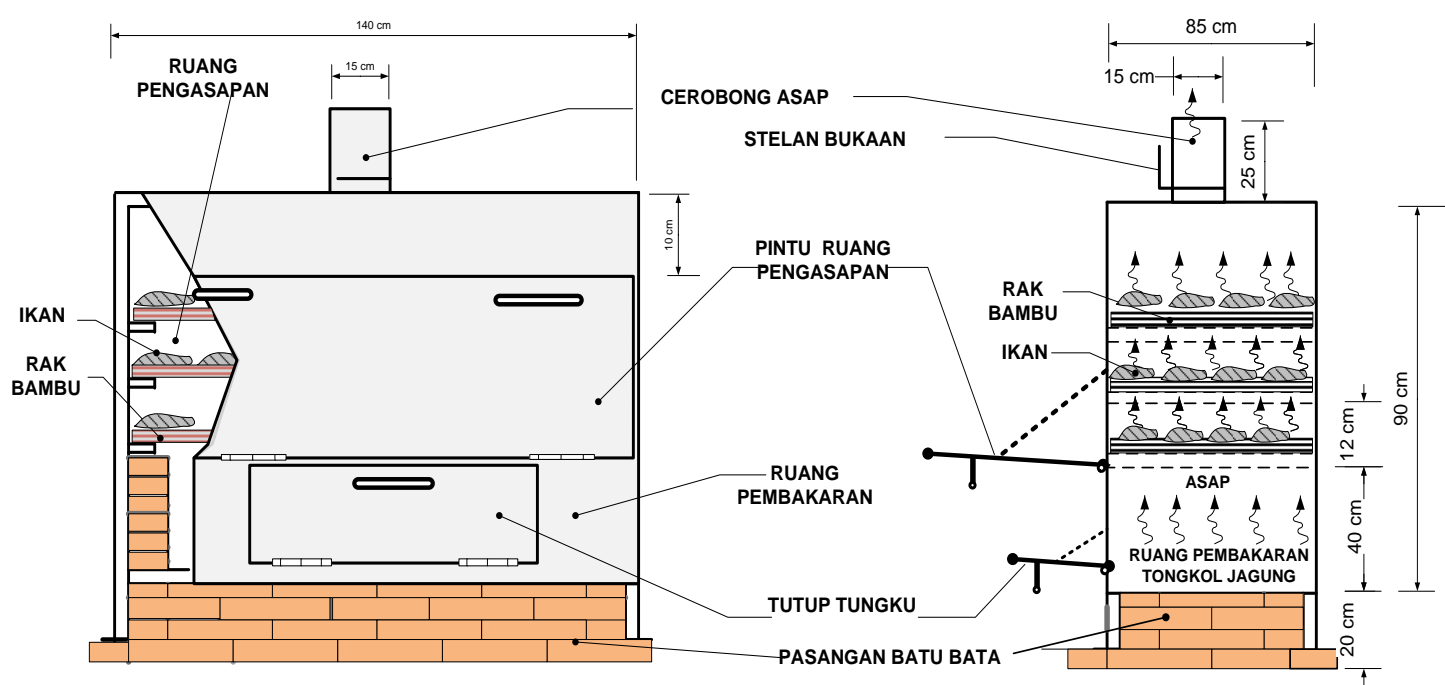

Gambar 3. Rancangan Alat Pengasap Program IbM

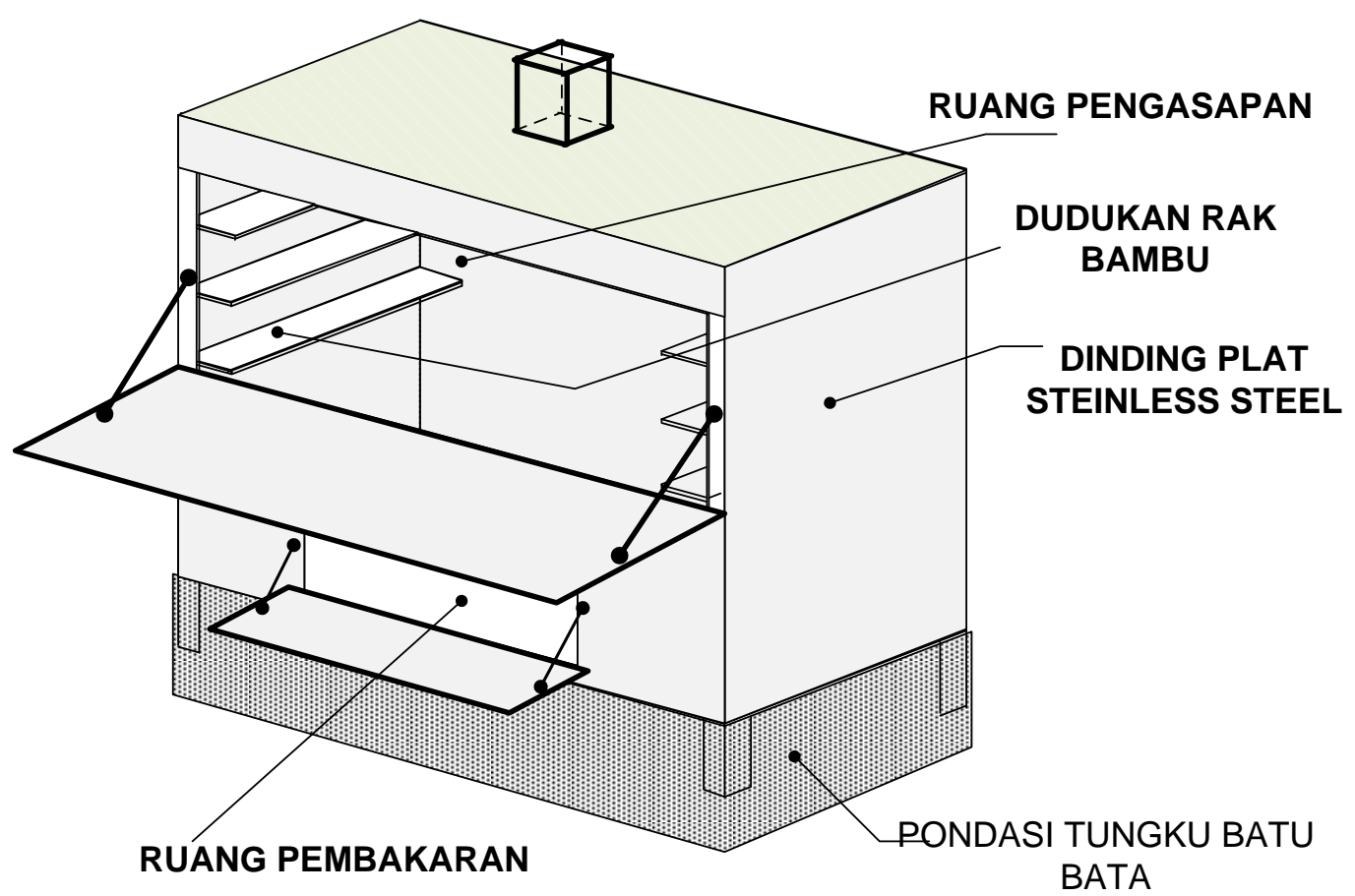

Gambar 4. Rancangan Tiga Dimensi Alat Pengasap Program Ibm

\subsection{Desain Fungsional dan Struktural \\ Alat Pengasap}

4.2.1 Cerobong Asap

Cerobong asap mempunyai fungsi sebagai saluran pengeluaran asap dari ruang pengasap. Cerobong asap dilengkapi dengan setelan bukaan yang berfungsi mengatur jumlah asap yang dipertahankan atau jumlah asap yang akan disalurkan ke udara bebas. Setelan asap berperan penting untuk menjaga jumlah asap yang dikehendaki. Dimensi cerobong asap berukuran panjang, lebar, tinggi berturut-turut $15 \mathrm{~cm}$ x $15 \mathrm{~cm}$ dan $25 \mathrm{~cm}$, sedangkan setelan bukaan terbuat dari plat ST 201 dengan dimensi panjang dan lebar berturut-turut $15 \mathrm{~cm}$. 


\subsubsection{Pintu Ruang Pengasapan}

Pintu ruang pengasapan berfungsi untuk memasukkan ikan yang akan diasap dan mengeluarkan ikan hasil pengasapan. Pintu ini berukuran panjang dan lebar berturut-turut $130 \mathrm{~cm}$ dan $40 \mathrm{~cm}$ terbuat dari plat ST 201.

4.2.3 Ruang Pembakaran

Ruang pembakaran merupakan tempat bahan bakar yang dibakar untuk menghasilkan asap. Bahan bakar yang digunakan adalah tongkol jagung. Dimensi ruang pembakaran berdimensi panjang, lebar dan tinggi berturut-turut $140 \mathrm{~cm}, 85$ $\mathrm{cm}$ dan $40 \mathrm{~cm}$. Ruang pembakaran dilengkapi dengan pintu pembakaran untuk memasukkan bahan bakar berupa tongkol jagung dan mengeluarkan abu tongkol jagung. Dimensi pintu tungku adalah panjang $100 \mathrm{~cm}$ dan tinggi $30 \mathrm{~cm}$ terbuat dari plat ST 201.

\subsubsection{Rak Bambu untuk Tempat Ikan Asap}

Rak tempat ikan asap terbuat dari bambu dengan dimensi panjang dan lebar berturut-turut $140 \mathrm{~cm}$ dan $85 \mathrm{~cm}$. Jarak antar rak setinggi $12 \mathrm{~cm}$ dimana terdapat 3 rak tempat ikan asap.
Sistem pengasapan yang dilakukan pengrajin adalah sistem tradisional terbuka menggunakan para-para dari bambu sedangkan model yang ditawarkan program ini adalah sistem tertutup menggunakan rak bertingkat dengan dimensi luasan rak adalah panjang dan lebar berturut-turut $140 \mathrm{~cm}$ dan $85 \mathrm{~cm}$ sebanyak 3 rak dengan jarak antar rak adalah $12 \mathrm{~cm}$.

Bahan bakar yang digunakan dalam proses pengasapan ikan adalah tongkol jagung. Uji organoleptik dilakukan meliputi rasa, warna, aroma dan tekstur.Hasil kajian terhadap hasil ikan asap sistem pengasapan tertutup dan pengasapan terbuka disajikan Tabel 1.

Secara umum pengasapan sistem tertutup menghasilkan produk dengan aroma, tekstur, rasa dan warna lebih baik dibandingkan pada pengolahan ikan asap sistem terbuka. Bahan bakar tongkol jagung yang digunakan juga lebih sedikit dengan waktu pengasapan lebih singkat yaitu sekitar 30-40\% lebih singkat.

Tabel 1. Perbandingan Alat Pengasap Sistem Tertutup Dan Terbuka (Konvensional)

\begin{tabular}{|c|c|c|}
\hline Uraian & $\begin{array}{l}\text { Sistem terbuka } \\
\text { (cara pengrajin) }\end{array}$ & $\begin{array}{l}\text { Sistem tertutup } \\
\text { (Introduksi IbM) }\end{array}$ \\
\hline Bentuk bangunan & $\begin{array}{l}\text { Tidak kompak, konstruksi } \\
\text { terbuka, terbuat dari batu bata }\end{array}$ & $\begin{array}{l}\text { Kompak, tertutup terbuat dari } \\
\text { bahan ST } 201\end{array}$ \\
\hline $\begin{array}{l}\text { Kapasitas } \\
\text { pengasapan }\end{array}$ & 3 rak & 3 rak \\
\hline Bahan bakar & Tongkol jagung & Tongkol jagung \\
\hline Panas dan asap & $\begin{array}{l}\text { Tidak terpusat pada produk } \\
\text { karena banyak terbuang ke } \\
\text { lingkungan }\end{array}$ & $\begin{array}{l}\text { Terpusat ke produk dan tidak } \\
\text { terbuang, asap bisa diatur melalui } \\
\text { pengaturan yang berada di } \\
\text { cerobong }\end{array}$ \\
\hline \multicolumn{3}{|l|}{ Kualitas } \\
\hline a. Warna & Kecoklatan & Kuning keemasan \\
\hline b. Rasa & Sedang & Sedang \\
\hline c. Tekstur & Kering & Sedang \\
\hline d. aroma & Kurang & Sedang \\
\hline Kemampuan alat & $\begin{array}{l}\text { Dipengaruhi tiupan angin dan } \\
\text { hujan }\end{array}$ & $\begin{array}{l}\text { Tidak terpengaruh oleh angin dan } \\
\text { hujan }\end{array}$ \\
\hline Pemeliharaan & Sulit & Mudah \\
\hline
\end{tabular}


Problem utama dalam proses pembuatan ikan asap dengan bahan ikan hiu dan ikan pari adalah pada tahap pencucian. Tingginya kandungan lemak, protein larut air, pigmen dan trimetilamin oksida (TMAO) pada daging hiu dan ikan pari, maka dianjurkan adanya tahapan pencucian lebih lanjut untuk mendapatkan kualitas ikan asap yang baik. Penampakan daging hiu dan ikan pari kurang disukai karena terjadinya perubahan warna daging yang cenderung menjadi lebih gelap selama penyimpanan, memiliki bau amoniak (jawa: pesing) serta adanya kandungan asam lemak bebas relatif lebih besar sehingga merangsang reaksi oksidasi (Spinelli dan Dassow, 1982).

Proses pengasapan ikan hiu dan ikan pari menggunakan pencucian dengan metode perendaman atau pencucian dengan air bersih, mestinya menggunakan larutan garam alkali 0,5 \% sodium bikarbonat (Flick et al., 1990), sedangkan Kelleher et al. (1992) menggunakan penambahan 0,02 \% Tert-butilhidroquinon (TBHQ).

Setiap hari industri pemanggangan ikan dan ikan asap di sentra rata-rata membutuhkan bahan baku sebesar $742,5 \mathrm{~kg}$ bahan baku ikan pari dan ikan hiu. Berdasarkan pengamatan di lapangan perbandingan jumlah ikan pari: hiu yang diolah adalah sebesar 70: 30. Untuk meningkatkan kualitas dan nilai jual ikan asap maka perlu dilakukan tahapan pencucian menggunakan ozon.

\section{KESIMPULAN DAN SARAN \\ 5.1 Kesimpulan}

Kesimpulan dari kegiatan ini adalah sebagai berikut:

a. Alat pengasap sistem tertutup introduksi program mempunyai keunggulan dibandingkan dengan sistem konvensional (terbuka), di antaranya adalah: bentuk bangunan lebih kompak, penggunaan asap terpusat ke produk dan tidak hilang ke lingkungan, jumlah asap bisa diatur melalui saluran pengaturan yang ada di cerobong, produk dari sisa warna lebih baik (warna keemasan), dari sisi tekstur dan aroma tergolong sedang, tidak terpengaruh oleh angin dan hujan dan sistem pemeliharaannya mudah.

b. Alat sistem pengasap tertutup lebih higienis dan anti karat sehingga lebih mudah dalam pemeliharaan.

\subsection{Saran}

Alat pengasap sistem tertutup introduksi program ini terbuat dari bahan ST 201 sehingga untuk menjaga kebersihan maka sesudah digunakan harus dibersihkan menggunakan kain basah agar warna tidak terkontaminasi oleh minyak ikan (coklat).

\section{DAFTAR PUSTAKA}

Adawyah R. 2007. Pengolahan dan Pengawetan Ikan. Penerbit Bumi Aksara. Jakarta

Afrianto E, E Liviawaty. 2005. Pengawetan dan Pengolahan Ikan. Penerbit Kanisius. Yogyakarta.

Afrianto A. 1989. Pengawetan dan Pengolahan Ikan. Penerbit Kanisius. Jakarta

Andini YS. 2006. Karakteristik Surimi Hasil Ozonisasi Daging Merah Ikan Tongkol Euthynnus sp.). Skripsi. Fakultas Perikanan Institut Pertanian Bogor.

Ashbrook FG. 1955. Butchering, Processing and Preservation of Meat. D Van Nostrand Company, Inc. Canada.

Astawan M. 1997. Mengenal Makanan Tradisional (2) Produk Olahan Ikan. Buletin Teknologi dan Industri Pangan. Vol VIII. No.3.

Direktorat Kredit, BPR dan UMKM. 2009. Pola Pembiayaan Usaha Penangkapan Ikan. http://www.bi.go.id. 
Hukmi, F. 2010. Analisis Kelayakan Pengembangan Usaha Pengolahan Ikan Asap (Kasus Pada Aneka Ikan Asap IACHI Petikan Cita Halus (Pch), Desa Raga Jaya, Kecamatan Citayam, Kabupaten Bogor, Jawa Barat. Skripsi. Program Studi Agribisnis, Fakultas Ekonomi dan Manajemen, Institut Pertanian Bogor.

Irianto, H.E. dan S. Giyatmi. 2009. Teknologi Pengolahan Hasil
Perikanan. Universitas Terbuka. Jakarta.

Maripul. 2004. Kajian Alat Pengasap Ikan Sistem Terbuka dan Tertutup. Buletin Teknik Pertanian Vol. 9, Nomor 1.

Okuzumi, M. and T. Fuji. 2000. Nutritional And Functional Properties Of Squid And Cuttlefish. National Cooperative Association of Squid Processors. Tokyo. 